\author{
N.A. Bokayev ${ }^{1}$, M.L. Goldman ${ }^{2}$, G.Zh. Karshygina ${ }^{1}$ \\ ${ }^{1}$ L.N. Gumilyov Eurasian National University, Astana, Kazakhstan; \\ ${ }^{2}$ Peoples' Friendship University of Russia, Moscow \\ (E-mail: karshygina84@mail.ru)
}

\title{
Some integral estimates on the cones of functions with the monotonicity conditions
}

\begin{abstract}
In this paper we obtain estimates for the integrals of monotone functions arising in the study of the covering of various cones of functions with monotonicity conditions. We apply the method of covering of the cones with the help of generalized Hardy operator. Sharp conditions are found on the kernels of representations for the validity of given estimates on the cones. The proofs are based on the reduction of integral estimates on the cones of monotone functions to ones on the family of characteristic functions of intervals. The obtained results can be used in finding the condition for the mutual covering of cones associated with decreasing rearrangement of the generalized Bessel and Riesz potentials.
\end{abstract}

Keywords: functional norm, cones of functions with monotonicity conditions, covering of cones.

When studying the embedding of the potential spaces in rearrangement-invariant spaces, various cones of functions with monotonicity conditions arise. In terms of such cones, we can formulate the embedding criteria for the space of generalized Bessel and Riesz potentials in rearrangement invariant spaces [1-3]. In this case, an important role is played by problems of ordinal covering of cones.

Let $(S, \Sigma, \mu)$ be a measure space. Here $\Sigma$ is $\sigma$-algebra of subsets of the set $S$, on which is determined a nonnegative $\sigma$ - finite, $\sigma$ - aditive measure $\mu . L_{0}=L_{0}(S, \Sigma, \mu)$ denotes the set $\mu$-measurable real-valued functions $f: S \rightarrow R, L_{0}^{+}=\left\{f \in L_{0}: f \geq 0\right\}$.

Definition 1. [4] Mapping $\rho: L_{0}^{+} \rightarrow[0, \infty]$ is called a functional norm (short: FN), if for all $f, g, f_{n} \in L_{0}^{+}$, $n \in N$ the conditions are fulfilled:

(P1) $\quad \rho(f)=0 \Rightarrow f=0, \mu$ - almost everywhere (short: $\mu$ - a.e.);

$\rho(\alpha f)=\alpha \rho(f), \alpha \geq 0 ; \rho(f+g) \leq \rho(f)+\rho(g)$ (property of the norm);

$(P 2) \quad f \leq g,(\mu-$ a.e. $) \Rightarrow \rho(f) \leq \rho(g)$ (monotonicity of the norm);

$(P 3) \quad f_{n} \uparrow f \Rightarrow \rho\left(f_{n}\right) \rightarrow \rho(f)(n \rightarrow \infty)$ (Fatou property);

(P4) $0<\mu(\sigma)<\infty \Rightarrow \int_{\sigma} f d \mu \leq c_{\sigma} \rho(f), f \in L_{0}^{+}$. (Local integrability);

(P5) $0<\mu(\sigma)<\infty \Rightarrow \rho\left(\chi_{\sigma}\right)<\infty$ (finiteness of the FN for characteristic functions $\left(\chi_{\sigma}\right)$ for the sets of finite measure).

Here $f_{n} \uparrow f$ means that $f_{n} \leq f_{n+1}, \lim _{n \rightarrow \infty} f_{n}=f(\mu-$ a.e. $)$

Definition 2. Let $\rho$ be a functional norm. Set $X=X(\rho)$ of functions in $L_{0}$, for which $\rho(|f|)<\infty$ is called a Banach function space, generated by a FN $\rho$. For $f \in X$ we set

$$
\|f\|_{X}=\rho(|f|) .
$$

Let relations of partial order and equivalence be introduced on $L_{0}^{+}$:

$f \prec g$ with properties of transitivity, i.e. $f \prec f$;

$$
f \prec g, \quad g \prec h \Rightarrow f \prec h ; \quad f \approx g \Leftrightarrow f \prec g \prec f .
$$

We assume, that the order relation is subordinated to pointwise estimate $\mu$-a.e., i.e.

$$
\text { 1) } f \leq g, \quad(\mu-\text { a.e. }) \Rightarrow f \prec g ; \quad \text { 2) } \quad f_{n} \uparrow f \Rightarrow f_{n} \uparrow f .
$$

Here $f_{n} \uparrow f$ means that $f_{n} \prec f_{n+1} ; f=[\sup ] f_{n} \quad$ i.e. $\quad f_{n} \prec f n \in N$ and, if $f_{n} \prec \hat{f}, n \in N$ then $f \prec \hat{f}$. A basic example of the order relation: $f \prec g \Leftrightarrow f \leq g, \quad \mu$-a.e. $\Rightarrow \rho(f) \leq \rho(g)$. 
We are interested in the relation of the order associated with the decreasing rearrangement of functions. Denote for $f \in L_{0}$

$$
\lambda_{f}(y)=\mu\{x \in S:|f(x)|>y\}, \quad y \in[0, \infty)
$$

- Lebesgue distribution function. Through $\dot{L}_{0}$ denote the set of functions $f \in L_{0}$ for which $\lambda_{f}(y)$ is not identical to infinity, i.e. $\exists y_{0} \in[0, \infty): \quad \lambda_{f}\left(y_{0}\right)<\infty$. For $f \in \dot{L}_{0}$ we introduce a decreasing rearrangement $f^{*}$ as a right inverse function of a decreasing function $\lambda_{f}$, i.e.

$$
f^{*}(t)=\inf \left\{y \in[0, \infty): \quad \lambda_{f}(y) \leq t\right\}, \quad t \in R_{+}=(0, \infty) .
$$

It is known that $0 \leq f^{*} \downarrow ; \quad f^{*}(t+0)=f^{*}(t), \quad t \in R_{+} ; f^{*}$ is equimeasurable with $|f|$, i.e. $\mu_{1}\left\{t \in R_{+}: f^{*}(t)>y\right\}=\lambda_{f}(y), \quad y \in[0, \infty)$. In addition, for $f \in \dot{L}_{0}$ we have: $\lambda_{f}(y) \rightarrow 0, \quad(y \rightarrow+\infty) \Leftrightarrow$ $\Leftrightarrow|f(x)|<\infty$, $(\mu-$ a.e. $)$ on $S$.

We define the order relations for the functions from $\dot{L}_{0}^{+}$:

$$
\begin{gathered}
\text { 1) } f \prec g \Leftrightarrow f^{*}(t) \leq g^{*}(t) ; \quad t \in(0, \mu(S)) ; \\
\text { 2) } f \prec g \Leftrightarrow \int_{0}^{t} f^{*} d \tau \leq \int_{0}^{t} g^{*} d \tau ; \quad t \in(0, \mu(S)) .
\end{gathered}
$$

The order relation (5) is subordinate to (4); both are subordinate to pointwise estimation $\mu$-a.e.. The equivalence of functions by order relation (4) means equimeasurability.

Definition 3. Let $\rho$ be a FN. We say that $\rho$ is consistent with the order relation $\prec$, if for $f, g \in L_{0}^{+}, f \prec g$ we have $\rho(f) \leq \rho(g)$.

Let us note that by property $(P 2)$ any $\mathrm{FN}$ is consistent with a pointwise estimate:

$$
f \leq g \quad(\mu-\text { a.e. }) \Rightarrow \rho(f) \leq \rho(g)
$$

Definition 4. A FN $\rho$ is rearrangement-invariant if it is compatible with the order relation (4) i.e.

$$
f^{*} \leq g^{*} \Rightarrow \rho(f) \leq \rho(g)
$$

BFS $X=X(\rho)$, generated by rearrangement-invariant FN $\rho$, we call as rearrangement-invariant space (short: RIS).

Let $K, M \subset L_{0}^{+}$be cones of functions [5], equipped with non-degenerate positive homogeneous functionals $\rho_{K}$, and $\rho_{M}$ i.e.

$$
\rho_{K}: \quad K \rightarrow[0, \quad \infty) ; \quad h \in K \Rightarrow \alpha h \in K, \quad \alpha \geq 0 ; \quad \rho_{K}(\alpha h)=\alpha \rho_{K}(h) ;
$$

$\rho_{K}(h)=0 \Rightarrow h=0, \quad \mu$ - a.e. and analogous for $\rho_{M}(h) h \in M$.

Let on the $L_{0}^{+}$given order relation $\prec$. Following [6], we introduce the notions of ordinal covering and order equivalence of cones.

Definition 5. Cone $M$ covers the cone $K$ with the covering constants $c_{0} \in R_{+}$and $c_{1} \in[0, \infty)$ if for any $h_{1} \in K$ there exits $h_{2} \in M$ such that

$$
\rho_{M}\left(h_{2}\right) \leq c_{0} \rho_{K}\left(h_{1}\right), \quad h_{1} \prec h_{2}+c_{1} \rho_{K}\left(h_{1}\right) .
$$

Designation of an ordinal covering: $K \prec M$.

Definition 6 . We call the cones $K, M$ order-equivalent, if they mutually over each other.

The designation of ordinal equivalence:

$$
K \approx M \Leftrightarrow K \prec M \prec K .
$$

If the order relation $\prec$ coincides with a pointwise estimate of the functions $\mu$-a.e., we will talk about pointwise covering of the cones and write $K \leq M$. So when $K \leq M$ (8) takes the form

$$
\rho_{M}\left(h_{2}\right) \leq c_{0} \rho_{K}\left(h_{1}\right), \quad h_{1} \leq h_{2}+c_{1} \rho_{K}\left(h_{1}\right), \quad(\mu-\text { a.e. }) .
$$


Pointwise equivalence of the cones signifies their mutual pointwise covering and is denoted: $K \cong M$. So,

$$
K \cong M \Leftrightarrow K \leq M \leq K .
$$

Let $T \in(0, \infty]$. Through $\Omega(T)$ denote the class of functions on $(0, T)$ :

$$
\Omega(T)=\left\{\varphi: \quad 0<\varphi(t) \downarrow ; \quad \int_{0}^{t} \varphi d \xi<\infty ; \quad \varphi(t+0)=\varphi(t), \quad t \in(0, T)\right\} .
$$

We introduce the functions of two variables $t, \tau \in(0, T)$

$$
\begin{gathered}
f_{\varphi}(t, \tau)=\min \left\{\varphi(t),(\varphi(\tau)\}= \begin{cases}\varphi(t), & \tau \in(0, t] ; \\
\varphi(\tau), & \tau \in(t, T) ;\end{cases} \right. \\
\tilde{f}_{\varphi}(t, \tau)= \begin{cases}\frac{1}{t} \int_{0}^{t} \varphi(\xi) d \xi, & \tau \in(0, t] ; \\
\varphi(\tau), & \tau \in(t, T) .\end{cases}
\end{gathered}
$$

It is clear that $f_{\varphi}(t, \tau)$ decreases and is continuous from the right by $t$ and on $\tau$. Further,

$$
\varphi \in \Omega(T) \Rightarrow \frac{1}{t} \int_{0}^{t} \varphi(\xi) d \xi \geq \varphi(t), \quad t \in(0, T)
$$

so that

$$
0 \leq f_{\varphi}(t, \tau) \leq \tilde{f}_{\varphi}(t, \tau), \quad t, \tau \in(0, T)
$$

and $\tilde{f}_{\varphi}(t, \tau)$ decreases by $\tau$ on the $(0, T)$. Now space with a measure $(S, \Sigma, \mu)$ is given as follows: $S=(0, T)$; $\Sigma$ there is $\sigma$-algebra of Lebesgue-measurable subsets of $(0, T), \mu$ is Lebesgue measure. Let $E=E(0, T)$ be an RIS of measurable functions on $(0, T)$ with decreasing rearrangements with respect to Lebesgue measure $\mu$;

$$
E^{\downarrow}=E^{\downarrow}(0, T)=\{g \in E(0, T): \quad 0 \leq g \downarrow \quad \text { on } \quad(0, T)\} .
$$

We introduce the cones of functions from $L_{0}^{+}(0, T)$ :

$$
\begin{aligned}
& K(T)=K_{\varphi, E}(T)=\left\{h(t) \equiv h(g ; t):=\int_{0}^{T} f_{\varphi}(t, \tau) g(\tau) d \tau: \quad g \in E^{\downarrow}\right\} ; \\
& \tilde{K}(T)=\tilde{K}_{\varphi, E}(T)=\left\{\tilde{h}(t) \equiv \tilde{h}(g ; t):=\int_{0}^{T} \tilde{f}_{\varphi}(t, \tau) g(\tau) d \tau: \quad g \in E^{\downarrow}\right\} .
\end{aligned}
$$

Cones $K$ and $\tilde{K}$ are equipped with functionals: for $h \in K, \quad \tilde{h} \in \tilde{K}$

$$
\begin{aligned}
& \rho_{K}(h)=\inf \left\{\|g\|_{E}: \quad g \in E^{\downarrow} ; \quad h(g ; t)=h(t), \quad t \in(0, T)\right\} ; \\
& \rho_{\tilde{K}}(\tilde{h})=\inf \left\{\|g\|_{E}: \quad g \in E^{\downarrow} ; \quad \tilde{h}(g ; t)=\tilde{h}(t), \quad t \in(0, T)\right\} .
\end{aligned}
$$

We denote for $\varphi>0, \varphi \downarrow$,

$$
B_{\varphi}:=\sup _{t \in(0, T)} \frac{\int_{0}^{t} \varphi(\xi) d \xi}{\frac{1}{t} \int_{0}^{t} \varphi(\xi) \xi d \xi} .
$$

When investigating the problems of the mutual covering of cones $K_{\varphi, E}(T)$ and $\tilde{K}_{\varphi, E}(T)$ the following statements of independent interest can be used. 
Theorem 1. Let $\varphi \in \Omega(T)$ see.(11) and $t \in(0, T)$. The following estimates are valid:

$$
\begin{gathered}
\int_{0}^{t} \varphi(\xi) d \xi \leq \sup _{\rho \in(0, t]}\left\{\frac{1}{\rho} \int_{0}^{\rho}\left[\varphi(\tau) \tau+\int_{\tau}^{t} \varphi(\xi) d \xi\right] d \tau\right\} \leq 2 \int_{0}^{t} \varphi(\xi) d \xi ; \\
\frac{1}{t} \int_{0}^{t} \varphi(\tau) \tau d \tau \leq \inf _{\rho \in(0, t]}\left\{\frac{1}{\rho} \int_{0}^{\rho}\left[\varphi(\tau) \tau+\int_{\tau}^{t} \varphi(\xi) d \xi\right] d \tau\right\} \leq \frac{2}{t} \int_{0}^{t} \varphi(\tau) \tau d \tau .
\end{gathered}
$$

Proof.

At $\rho \in(0, t]$ we have

$$
\begin{gathered}
\int_{0}^{\rho}\left[\varphi(\tau) \tau+\int_{\tau}^{t} \varphi(\xi) d \xi\right] d \tau=\int_{0}^{\rho} \varphi(\tau) \tau d \tau+\int_{0}^{\rho}\left(\int_{\tau}^{t} \varphi(\xi) d \xi\right) d \tau=\int_{0}^{\rho} \varphi(\tau) \tau d \tau+ \\
\quad+\int_{0}^{\rho} \varphi(\xi)\left(\int_{0}^{\xi} d \tau\right) d \xi+\int_{\rho}^{t} \varphi(\xi)\left(\int_{0}^{\rho} d \tau\right) d \xi=2 \int_{0}^{\rho} \varphi(\tau) \tau d \tau+\rho \int_{\rho}^{t} \varphi(\xi) d \xi .
\end{gathered}
$$

We denote by

$$
\begin{array}{ll}
\Psi(\rho)=\frac{1}{\rho} \int_{0}^{\rho} \varphi(\tau) \tau d \tau+\int_{\rho}^{t} \varphi(\xi) d \xi, & \rho \in(0, t] \\
Q(\rho)=\frac{1}{\rho} \int_{0}^{\rho}\left[\varphi(\tau) \tau+\int_{\tau}^{t} \varphi(\xi) d \xi\right] d \tau, & \rho \in(0, t] .
\end{array}
$$

Then

$$
\Psi(\rho) \leq Q(\rho) \leq 2 \Psi(\rho) .
$$

We note that the function $\Psi(\rho)$ decreases monotonically on $(0, t]$. Indeed, since $\Psi^{\prime}(\rho)=-\frac{1}{\rho^{2}} \int_{0}^{\rho} \varphi(\tau) \tau d \tau<0$ therefore $\Rightarrow \Psi(\rho) \downarrow$.

Consequently,

$$
\sup _{\rho \in(0, t]} \Psi(\rho)=\Psi(+0)=\int_{0}^{t} \varphi(\xi) d \xi .
$$

In the formula for $\Psi(+0)$ we took into account that

$$
\frac{1}{\rho} \int_{0}^{\rho} \varphi(\tau) \tau d \tau \leq \int_{0}^{\rho} \varphi(\tau) d \tau \rightarrow 0 \quad(\rho \rightarrow+0)
$$

Moreover

$$
\inf _{\rho \in(0, t]} \Psi(\rho)=\Psi(t)=\frac{1}{t} \int_{0}^{t} \varphi(\tau) \tau d \tau .
$$

From this and (24) follow the estimates (22), (23).

Corollary 1. Under the conditions of Theorem 1, for $\rho \in(0, t], t \in(0, T)$ the estimate holds

$$
\frac{1}{t} \int_{0}^{t} \varphi(\tau) \tau d \tau \leq \frac{1}{\rho} \int_{0}^{\rho}\left[\varphi(\tau) \tau+\int_{\tau}^{t} \varphi(\xi) d \xi\right] d \tau \leq 2 \int_{0}^{t} \varphi(\xi) d \xi .
$$


If $B_{\varphi}<\infty$ (see.(21)), then with $\rho \in(0, t], t \in(0, T)$ the estimates hold

$$
\begin{gathered}
\frac{1}{B_{\varphi}} \int_{0}^{t} \varphi(\xi) d \xi \leq \frac{1}{\rho} \int_{0}^{\rho}\left[\varphi(\tau) \tau+\int_{\tau}^{t} \varphi(\xi) d \xi\right] d \tau \leq 2 \int_{0}^{t} \varphi(\xi) d \xi \\
\frac{1}{t} \int_{0}^{t} \varphi(\tau) \tau d \tau \leq \frac{1}{\rho} \int_{0}^{\rho}\left[\varphi(\tau) \tau+\int_{\tau}^{t} \varphi(\xi) d \xi\right] d \tau \leq \frac{2 B_{\varphi}}{t} \int_{0}^{t} \varphi(\tau) \tau d \tau .
\end{gathered}
$$

Theorem 2. Under the conditions of Theorem 1, we denote (see (17), (18)):

$$
\hat{C_{\varphi, t}}=\sup _{g \in E^{\downarrow}}\left[\frac{\tilde{h}(g ; t)}{\frac{1}{t} \int_{0}^{t} h(g ; \xi) d \xi}\right] ; \quad \hat{C}_{\varphi}=\sup _{g \in(0, t)} \hat{C_{\varphi, t}} .
$$

Then the following estimates hold

$$
\frac{1}{2} B_{\varphi} \leq \hat{C}_{\varphi} \leq B_{\varphi}+1 .
$$

Proof. Let $h \in K_{\varphi, E}(T) . g \in E^{\downarrow}(0, T)$, be such that

$$
h(t)=h(g ; t)=\int_{0}^{T} f_{\varphi}(t, \tau) g(\tau) d \tau ; \quad\|g\|_{E} \leq 2 \rho_{K}(h) .
$$

It follows that

$$
\int_{0}^{t} h(g ; \xi) d \xi=\int_{0}^{T} g(\tau)\left(\int_{0}^{t} f_{\varphi}(\xi, \tau) d \xi\right) d \tau, \quad t \in(0, T)
$$

According to (12)

$$
f_{\varphi}(\xi, \tau)=\varphi(\tau), \quad \xi \in(0, \tau] ; \quad f_{\varphi}(\xi, \tau)=\varphi(\xi), \quad \xi \in(\tau, T),
$$

so that

$$
\int_{0}^{t} h(g ; \xi) d \xi=\int_{0}^{T} g(\tau)\left[\left(\varphi(\tau) \tau+\int_{\tau}^{t} \varphi(\xi) d \xi\right) \chi_{(0, t)}(\tau)+t \varphi(\tau) \chi_{(t, T)}(\tau)\right] d \tau .
$$

It follows from (13) that

$$
t \tilde{h}(g ; t)=\int_{0}^{T} g(\tau)\left[\left(\int_{0}^{t} \varphi d \xi\right) \chi_{(0, t]}(\tau)+t \varphi(\tau) \chi_{(t, T)}(\tau)\right] d \tau .
$$

So,

$$
\hat{C}_{\varphi, t}=\sup _{g \in E \downarrow}\left[\frac{\int_{0}^{T} g(\tau)\left[\left(\int_{0}^{t} \varphi d \xi\right) \chi_{(0, t)}(\tau)+t \varphi(\tau) \chi_{(t, T)}(\tau)\right] d \tau}{\left.\int_{0}^{T} g(\tau)\left[\left(\varphi(\tau) \tau+\int_{\tau}^{t} \varphi d \xi\right) \chi_{(0, t)}(\tau)+t \varphi(\tau) \chi_{(t, T)}(\tau)\right] d \tau\right]}\right] .
$$

All terms in the numerator and denominator in (32) are nonnegative, and the second summands coincide. Therefore, denoting

$$
\hat{D}_{\varphi, t}=\sup _{g \in E^{\downarrow}}\left[\frac{\int_{0}^{T} g(\tau)\left[\left(\int_{0}^{t} \varphi d \xi\right) \chi_{(0, t)}(\tau)\right] d \tau}{\left.\int_{0}^{T} g(\tau)\left[\left(\varphi(\tau) \tau+\int_{\tau}^{t} \varphi d \xi\right) \chi_{(0, t]}(\tau)+t \varphi(\tau) \chi_{(t, T)}(\tau)\right] d \tau\right]}\right],
$$


we get

$$
\hat{D}_{\varphi, t} \leq \hat{C}_{\varphi, t} \leq \hat{C}_{\varphi, t}+1
$$

Now denote

$$
\hat{E}_{\varphi, t}=\sup _{\rho \in(0, T)}\left[\frac{\int_{0}^{\rho}\left[\left(\int_{0}^{t} \varphi d \xi\right) \chi_{(0, t)}(\tau)\right] d \tau}{\left.\int_{0}^{\rho}\left[\left(\varphi(\tau) \tau+\int_{\tau}^{t} \varphi d \xi\right) \chi_{(0, t)}(\tau)+t \varphi(\tau) \chi_{(t, T)}(\tau)\right] d \tau\right]}\right] .
$$

As for any RIS $E(0, T)$ we have $g(\tau)=\chi_{(0, \rho)}(\tau) \in E^{\downarrow}(0, T)$ at $\rho \in(0, T)$ it is obvious that $\hat{D}_{\varphi, t} \geq \hat{E}_{\varphi, t}$. In fact, these quantities coincide (see, for example, $[5]$ );

$\hat{D}_{\varphi, t}=\hat{E}_{\varphi, t}$, so that

moreover, by virtue of $(22)$

$$
\hat{E}_{\varphi, t} \leq \hat{C}_{\varphi, t} \leq \hat{E}_{\varphi, t}+1
$$

$$
\hat{E}_{\varphi, t}=\max \left\{\hat{E}_{\varphi, t}^{0}, \hat{E}_{\varphi, t}^{1}\right\}
$$

where

$$
\begin{aligned}
& \hat{E}_{\varphi, t}^{(0)}:=\sup _{\rho \in(0, t)}\left[\frac{\int_{0}^{\rho}\left[\left(\int_{0}^{t} \varphi(\xi) d \xi\right) \chi_{(0, t]}(\tau)\right] d \tau}{\int_{0}^{\rho}\left(\varphi(\tau) \tau+\int_{\tau}^{t} \varphi(\xi) d \xi\right) \chi_{(0, t]}(\tau)+t \varphi(\tau) \chi_{(t, T)}(\tau) d \tau}\right]=\sup _{\rho \in(0, t]}\left[\frac{\rho\left(\int_{0}^{t} \varphi(\xi) d \xi\right)}{\left.\int_{0}^{\rho}\left(\varphi(\tau) \tau+\int_{\tau}^{t} \varphi(\xi) d \xi\right) d \tau\right]}\right] \\
& \hat{E}_{\varphi, t}^{(1)}:=\sup _{\rho \in(t, T)}\left[\frac{\int_{0}^{\rho}\left[\left(\int_{0}^{t} \varphi(\xi) d \xi\right) \chi_{(0, t]}(\tau)\right] d \tau}{\int_{0}^{\rho}\left(\varphi(\tau) \tau+\int_{\tau}^{t} \varphi(\xi) d \xi\right) \chi_{(0, t]}(\tau)+t \varphi(\tau) \chi_{(t, T)}(\tau) d \tau}\right]= \\
& =\sup _{\rho \in(t, T)}\left[\frac{t \int_{0}^{t} \varphi(\xi) d \xi}{\int_{0}^{t}\left(\varphi(\tau) \tau+\int_{\tau}^{t} \varphi d \xi\right) d \tau+t \int_{t}^{\rho} \varphi(\tau) d \tau}\right]
\end{aligned}
$$

In $\hat{E}_{\varphi, t}^{(1)}$ the upper bound is achieved when $\rho \in(t, T)$ has the minimum value $\rho=t$, so that

$$
\hat{E}_{\varphi, t}^{(1)} \leq \hat{E}_{\varphi, t}^{(0)}
$$

Thus,

$$
\hat{E}_{\varphi, t}=\hat{E}_{\varphi, t}^{(0)}=\sup _{\rho \in(0, t]}\left[\frac{\int_{0}^{t} \varphi d \xi}{\frac{1}{\rho} \int_{0}^{\rho}\left(\varphi(\tau) \tau+\int_{\tau}^{t} \varphi d \xi\right) d \tau}\right]
$$

Further, taking into account that

$$
\sup _{\rho \in(0, t]} \frac{\int_{0}^{t} \varphi(\xi) d \xi}{\frac{1}{\rho} \int_{0}^{\rho}\left(\varphi(\tau) \tau+\int_{\tau}^{t} \varphi(\xi) d \xi\right) d \tau}=\frac{\int_{0}^{t} \varphi(\xi) d \xi}{\inf _{\rho \in(0, t]} \frac{1}{\rho} \int_{0}^{\rho}\left(\varphi(\tau) \tau+\int_{\tau}^{t} \varphi(\xi) d \xi\right) d \tau}
$$

and applying Theorem 1 in the denominator, we obtain, by virtue of (23),

$$
\frac{t \int_{0}^{t} \varphi d \xi}{2 \int_{0}^{t} \varphi(\tau) \tau d \tau} \leq \hat{E}_{\varphi, t} \leq \frac{t \int_{0}^{t} \varphi d \xi}{\int_{0}^{t} \varphi(\tau) \tau d \tau}
$$


Therefore, on the base of (36), we have

$$
\frac{t \int_{0}^{t} \varphi d \xi}{2 \int_{0}^{t} \varphi(\tau) \tau d \tau} \leq \hat{C}_{\varphi, t} \leq \frac{t \int_{0}^{t} \varphi d \xi}{\int_{0}^{t} \varphi(\tau) \tau d \tau}+1, \quad \rho \in(0, T),
$$

from whence

$$
\frac{1}{2} B_{\varphi} \leq \hat{C}_{\varphi} \leq B_{\varphi}+1
$$

Theorem 2 is proved.

Corollary 2. Under the conditions of Theorem 2, the estimates hold

$$
\begin{gathered}
\tilde{h}(g ; t) \leq \hat{C}_{\varphi, t} \frac{1}{t} \int_{0}^{t} h(g ; \xi) d \xi, \\
\tilde{h}^{*}(g ; t) \leq \hat{C}_{\varphi, t} \frac{1}{t} \int_{0}^{t} h(g ; \xi) d \xi, \\
\|\tilde{h}(g ; \cdot)\|_{L_{\infty}(t, T)} \leq \hat{C}_{\varphi, t} \frac{1}{t} \int_{0}^{t} h(g ; \xi) d \xi,
\end{gathered}
$$

for all $t \in(0, T), \quad g \in E^{\downarrow}(0, T)$. Here $\hat{C}_{\varphi} \leq B_{\varphi}+1$.

Indeed, (40) follows from (29), and for $\hat{C}_{\varphi}$ the estimate (30) is valid. Moreover, on the right-hand side of (40) there is a positive, continuous decreasing function, as the mean integral with respect to $(0, t)$ of a decreasing function $h(g ; t)$, so

$$
\begin{gathered}
{\left[\frac{1}{\tau} \int_{0}^{t} h(g ; \xi) d \xi\right]^{*}=\frac{1}{\tau} \int_{0}^{t} h(g ; \xi) d \xi ;} \\
\left\|\frac{1}{t} \int_{0}^{\tau} h(g ; \xi) d \xi\right\|_{L_{\infty}(t, T)}=\frac{1}{t} \int_{0}^{\tau} h(g ; \xi) d \xi .
\end{gathered}
$$

Therefore, $(40) \Rightarrow(41),(42)$.

\section{References}

1 Гольдман М.Л. Об оптимальных вложениях потенциалов Бесселя и Рисса / М.Л. Гольдман // Труды Матем. института им. В.А.Стеклова. - М., 2010. - 269. - С. 91-111.

2 Goldman M.L. On the cones of rearrangements for generalized Bessel and Riesz potentials / M.L. Goldman // Complex Variables and Elliptic Equations. - 2010. - Vol. 55. - P. 817-832.

3 Каршыгина Г.Ж. Оптимальные вложения потенциалов типа Бесселя и Рисса на базе пространств Лоренца / Г.Ж. Каршыгина // Вестн. Караганд. ун-та. Сер. Математика. - 2017. - № 4(88). P. $15-25$.

4 Bennett C. Interpolation of Operators / C. Bennett, R.C. Sharpley. - New York: Academic Press, 1988.

5 Буренков В.И. Вычисление нормы положительного оператора на конусе монотонных функций / В.И. Буренков, М.Л. Гольдман // Труды Матем. института им. В.А. Стеклова. - 1995. - Вып. 210. - P. 65-89.

6 Бахтигареева Э.Г. Построение оптимальной оболочки для конуса неотрицательных функций со свойствами монотонности / Э.Г. Бахтигареева, М.Л. Гольдман // Труды Матем. института им. В.А.Стеклова. - 2016. - Вып. 293. - Р. 43-61. 


\title{
Н.А. Бокаев, М.Л. Гольдман, Г.Ж. Қаршығина
}

\section{Кейбір монотонды конустармен байланысты функциялар үшін бағалаулар}

\begin{abstract}
Мақалада монотонды шарттарға ие, әртүрлі функция конустарының көмкерілулерін (жабылуларын) зерттеу кезінде кездесетін монотондық функциялар үшін интегралдық бағалаулар алынған. Жалпыланған Харди операторы көмегімен конустардың операторлық көмкерілуі (жабылу) әдісі қолданылды. Келтірілген бағалаулардың дұрыстығы конустарды ұсынатын ядроларға нақты шарттар келтіру арқылы көрсетілген. Дәлелдеу аралықтардың сипаттамалық функцияларының арасындағы монотонды функциялар конустарының интегралдық бағалауларын редукциялаға негізделген. Алынған нәтижелер жалпыланған Бессел және Рисс түріндегі кемімелі ауыстырымдармен байланысқан конустардың өзара көмкерілуі (жабылу) шартарын іздестіру кезінде қолданылды.
\end{abstract}

Kiлm сөздер: функционалды норма, монотонды функциялар конусы, кемімелі алмастырылымды конустар, конустардың реттік бүркенуі.

\author{
Н.А. Бокаев, М.Л. Гольдман, Г.Ж. Каршыгина
}

\section{Некоторые интегральные оценки на конусах функций с условиями монотонности}

В статье получены интегральные оценки для монотонных функций, возникающие при изучении накрывания различных конусов функций с условиями монотонности. Использован метод операторного накрывания конусов с помощью обобщенного оператора Харди. Найдены точные условия на ядра представлений конусов, обеспечивающие справедливость приведенных оценок. Доказательства основаны на редукции интегральных оценок на конусах монотонных функций к оценкам на семействе характеристических функций интервалов. Полученные результаты могут быть применены при нахождении условий взаимного накрывания конусов, связанных с убывающими перестановками обобщенных потенциалов Бесселя и Рисса.

Ключевые слова: функциональная норма, конусы функций с условиями монотонности, порядковое накрывание конусов.

\section{References}

1 Goldman, M.L. (2010). Ob optimalnykh vlozheniiakh potentsialov Besselia i Rissa [Optimal embeddings of generalized Bessel and Riesz potentials]. Trudy Matematicheskoho instituta imeni V.A.Steklova Proceedings of the V.A.Steklov Institute of Mathematics, Vol. 269, 91-111 [in Russian].

2 Goldman, M.L. (2010). On the cones of rearrangements for generalized Bessel and Riesz potentials. Complex Variables and Elliptic Equations, Vol. 55, 817-832.

3 Karshygina, G.Zh. (2017). Optimalnye vlozheniia potentsialov tipa Besselia i Rissa na baze prostranstv Lorentsa [Optimal embeddings potentials type Bessel and Riesz on the base of Lorentz spaces]. Vestnik Karahandinskoho universiteta. Seriia Matematika - Bulletin of the Karaganda university. Series mathematics, 4(88), 15-25 [in Russian].

4 Bennett, C., \& Sharpley R.C. (1988). Interpolation of Operators. AP, New York: Academic Press.

5 Burenkov V. I., \& Goldman M.L. (1995). Vychislenie normy polozhitelnoho operatora na konuse monotonnykh funktsii. [Calculation of the norm of a positive operator on the cone of monotone functions]. Trudy Matematicheskoho instituta imeni V.A.Steklova-Proceedings of the V.A.Steklov Institute of Mathematics, Vol. 210, 65-89.

6 Bakhtigareeva, E.G., \& Goldman, M.L. (2016). Postroenie optimalnoi obolochki dlia konusa neotritsatelnykh funktsii so svoistvami monotonnosti [Construction of an optimal envelope for a cone of nonnegative functions with monotonicity properties]. Trudy Matematicheskoho instituta imeni V.A.Steklova - Proceedings of the V.A.Steklov Institute of Mathematics, Vol. 293, 43-61 [in Russian]. 